\title{
Geoelectrical Exploration of Groundwater by Using Vertical Electrical Sounding Technique at Wadi Morra, South Sinai, Egypt
}

\author{
Zayed MA* \\ Geology Department, Faculty of Science, Al-Azhar \\ University, Cairo, Egypt \\ *Corresponding author: Mahmoud A. Zayed, Geology \\ Department, Faculty of Science, Al-Azhar University, \\ Al Mokhaiam Al Daem, Al Nasr Road, Nasr City, Cairo, \\ Egypt
}

Received: May 31, 2021; Accepted: J uly 10, 2021;

Published: July 17, 2021

\begin{abstract}
Wadi Morra area is one of the most important areas targeted by the government for sustainable development. This development depends mainly on groundwater occurrences. This research aims to explore groundwater in this region, which depends on groundwater for its needs. To achieve this aim, the geoelectrical resistivity method was used, represented by Schlumberger Vertical Electrical Soundings (VESs). Seventeen VESs have been carried out with a maximum half current electrode spacing $(A B / 2)$ of $700 \mathrm{~m}$. The measured VESs are interpreted qualitatively and quantitatively to construct a geoelectrical model. To detect the water-bearing layers and their extensions, three geoelectric cross-sections in addition to a one-panel diagram were constructed using all the available data. Also, both true resistivity and isopach contour maps of waterbearing layers were created based on these data. The interpretation results indicate that there are five geoelectric layers $(A, B, C, D$, and $E)$, two of them (C and $D$ ) are water-bearing layers. The first water-bearing layer is layer $C$, which represents the Nubian sandstone aquifer, and the second layer is layer $D$, which represents the fractured basement aquifer. These two aquifers were observed along the northern part of the Saint Catherine - Nuweiba road that dissects the Wadi Morra basin, while it is absent at the southern part of this road. It is due to the presence of a few faults. According to groundwater occurrences, the study area was divided into two zones. The first zone is zone (A) where the groundwater is present, either in the Nubian sandstone aquifer or in the fractured basement aquifer and the second zone is zone (B) where there is no groundwater at all due to the presence of basement rocks at a few depths. This research also recommends that the best places for drilling productive wells be at zone $\mathrm{A}$.
\end{abstract}

Keywords: Groundwater; Geoelectrical resistivity; Vertical electrical sounding (VES); Nubian sandstone aquifer; Fractured basement aquifer

\section{Introduction}

A new community of the Bedouins is currently being established at the Wadi Morra area, as it serves the considerable inhabitants that are living in the Wadi Morra, Wadi Saal, and surrounding area. Wadi Morra represents one of the main tributaries of the Wadi Dahab basin and is located in the northern part of the Dahab basin (Figure 1). Wadi Morra dissects the high basement terrains of south Sinai province and drains eastwards to Wadi Al Ghaib that is a drain to the Gulf of Aqaba via Dahab city. It represents an elongated structural sandy plain that takes NW-SE direction [1], and covers an area of about $30 \mathrm{~km}^{2}$. Also, the main asphaltic road between Nuweiba and Saint Catherine is passing through this Wadi, for these reasons, this area is very important for development. Generally, the development of the arid and semiarid areas depends upon the groundwater occurrences and their proper utilization [2], Wadi Morra, and in general, South Sinai belongs to these areas. Groundwater is the only source of water in South Sinai and it is considered the key supply of safe drinking water for more than 104,000 people [3]. Also, groundwater is the only source of water in the Wadi Morra area, whether for drinking or other purposes. Therefore, groundwater exploration in this region is very important and vital for sustainable development. Many researchers explored groundwater in South Sinai, among them [2,4-7]. The results concluded, in its entirety, that there are three aquifers: the alluvial (Quaternary), the Nubian sandstone (Early Cambrian), and the fractured basement (PreCambrian) aquifers. There is a high difference in the groundwater occurrences at the structurally controlled areas like Wadi Morra. This difference is due to the nature of the geological structures that affect many valleys in South Sinai, and the amount of annual precipitation, where you find in the same valley large differences in the groundwater occurrences, as well as the thickness of the water-bearing layers. Also, there is a previous recommendation for conducting geophysical studies and drilling wells to explore the Nubian sandstone aquifer in Wadi Morra's depression [8]. From the above, the determination of water-bearing layers in such places is very important for sustainable development. In this manuscript, Vertical Electrical Sounding (VES) of the geoelectrical resistivity method was used for (1) groundwater exploration by detecting the areal extent and distribution of waterbearing layers at the foothills of the basement complex, and (2) detection of the probability for drilling production wells. 


\section{Site Description}

Generally, there are two main exposed groups of rock units across the Sinai Peninsula: (1) the Precambrian basement complex consisting of volcano-sedimentary basement rocks, (gneisses, volcano-sedimentary successions, and granitoids) which represent a part of the Arabian-Nubian Shield in the south Sinai; and (2) overlying by thick of the Phanerozoic sedimentary successions to the north Sinai $[9,10]$. Wadi Morra area represents a part of the south Sinai Peninsula, which located in the northern part of the ArabianNubian Shield. The study area is located in the center of the mentioned two main groups, where the Precambrian basement complex is exposed at the southern part and the Phanerozoic sedimentary rocks are exposed in the northern part of the study area (Figure 2). The exposed basement rocks in the study area are represented by Calc alkaline, quartz dioritic to granodioritic rocks, previously grey granite" or older granite [11]. The basement rocks are unconformably overlain by Lower Cretaceous of Malha Formation, which consists of unfossiliferous continental sandstone intercalated with shale of shallow marine and deltaic origin in central and southern Sinai [12], and Upper Jurassic to Lower Cretaceous fluviatile sandstone and conglomerate [13]. Malha Formation exposes at the foothills of the basement complex, which increases opportunities for groundwater recharge for the Nubian Sandstone aquifer [5].

These Precambrian and Phanerozoic rocks are covered by Quaternary Wadi deposits, which consist of erosional products of sedimentary and igneous rocks. These deposits fill the Wadi floors in the basement terrains with variable textures and thicknesses ranging between a few meters up to 60 meters in the delta Dahab area $[14,15]$. They are composed of rock fragments, fine to coarse sands, gravel, and boulders (derived mainly from the disintegration of the basement rocks) that embedded in a silty and clayey matrix [16]. Structurally, Wadi Morra is controlled by major faults having both NW-SE and NE-SW directions. They have a significant contribution to the subsurface groundwater occurrences. Hydrogeologically, there are three aquifers in south Sinai: the alluvial (Quaternary), the Nubian sandstone (Early Cambrian), and the fractured basement (PreCambrian) aquifers $[6,17,18]$. The amount of annual precipitation plays an important role in recharging these aquifers [5]. Generally, the Sinai Peninsula receives relatively high amounts of precipitation compared to the other Egyptian desert areas. The average annual precipitation over the Western Desert, Eastern Desert, and Sinai was found to be $9 \mathrm{~mm} / \mathrm{yrs}, 13 \mathrm{~mm} / \mathrm{yrs}$, and $70 \mathrm{~mm} / \mathrm{yrs}$, respectively [19]. The Southern Sinai area that contains mountainous basement rocks is received the high amounts of precipitation in Sinai [20,21]; precipitation is collected and channeled through main streams by the extensive stream network, which distributed in the study area.

\section{Materials and Methods}

Geoelectrical Resistivity investigations were conducted by using Schlumberger VES technique, this technique has been widely utilized for groundwater exploration studies at the south Sinai area $[2,5,7,22]$. ABEM Terameter SAS 1000 was used for surveying of all VESs, applying the Schlumberger configuration. The current electrode separation $(\mathrm{AB})$ ranges between 2 and $1400 \mathrm{~m}$. that is sufficient to reach the basement rocks. A total of seventeen VESs were measured in the plain area of Wadi Morra (Figure 3), one of them was measured beside the Wadi Morra productive well (there is only one well in the study area until March 2019) to be used for calibration during the quantitative interpretation. The measured VESs are interpreted qualitatively and quantitatively to build a geoelectrical model. The qualitative interpretation is represented by iso-apparent resistivity contour maps at the half current electrode separation $(\mathrm{AB} / 2)$ from 1 to $700 \mathrm{~m}$, these maps were constructed to show the lateral variation in the apparent resistivity at a different spacing which indicates to depths. The IPI2Win (2008) software was used for quantitative interpretation of the conducted VESs and for building the geoelectric model by the estimation of the true resistivity ( $\rho$ a) and thickness (h) of each geoelectric layer. The Root Means Square (RMS) errors that are given for the interpreted VESs ranges between 2 and 7, which indicate that there is a good fitting for the generated geoelectric models. For detecting the water-bearing layers and its extensions, three geoelectric cross-sections in addition to one-panel diagram were constructed using all the available data. These data include the layers resistivities and thicknesses as well as the geologic and hydrogeologic information (e.g. lithology, structural information, and depth to the water table). Also, both true resistivity and isopach contour maps of water-bearing layers were created based on these data.

\section{Results and Discussion}

\section{Qualitative interpretation}

The iso-apparent resistivity contour maps at different half-current electrode spacing $(\mathrm{AB} / 2)$ represents the main item for qualitative interpretation.

Iso-apparent resistivity contour maps: The iso-apparent resistivity contour maps were constructed to show the lateral variations in the apparent electric resistivity at all spacing $(\mathrm{AB} / 2$ from 1 to 700), which indicate different depths. A number of these maps were chosen to illustrate the difference in apparent resistivity (Figure 4). The description of these maps is as the following: Firstly, the apparent resistivity contour maps of $\mathrm{AB} / 2$ equal 1 and $10 \mathrm{~m}$ have a wide range of resistivity from 45 to $1696 \Omega$.m. This range of resistivity due to the surface layer that combines different Wadi deposits. The low resistivity corresponds to Quaternary alluvium that consists of intruded clay with sand deposits, whereas the high resistivity value corresponds to boulders, gravel, sands, and sandstone. Secondly, it is easy to notice the relative decreases of the apparent resistivity at $\mathrm{AB} / 2$ equal $100 \mathrm{~m}$ as it ranges from 84 to $730 \Omega . \mathrm{m}$ but there is increasing in the apparent resistivity at the southwestern part, which may indicate the beginning of the appearance of basement rocks. Thirdly, the apparent resistivity map at $\mathrm{AB} / 2$ equal 150 and $300 \mathrm{~m}$ indicates that the apparent resistivity values range from 101 to $1935 \Omega$.m. The high values are located at the southwestern part (where the basement is located) while the rest parts of the map have relatively low resistivity values ranges from about 100 to $300 \Omega$.m may be due to the presence of water-bearing layers. Finally, the apparent resistivity map has a relative increase of the apparent resistivity at $A B / 2$ equal to $700 \mathrm{~m}$ as it ranges from 319 to $3686 \Omega$.m. These high values indicate the presence of the basement rocks.

\section{Quantitative interpretation}

Geoelectrical cross-sections: Three geoelectrical cross-sections have been built based on the given geoelectric model (Figure 5), which was created by IPI2Win [23] software (Table 1). These cross-sections 


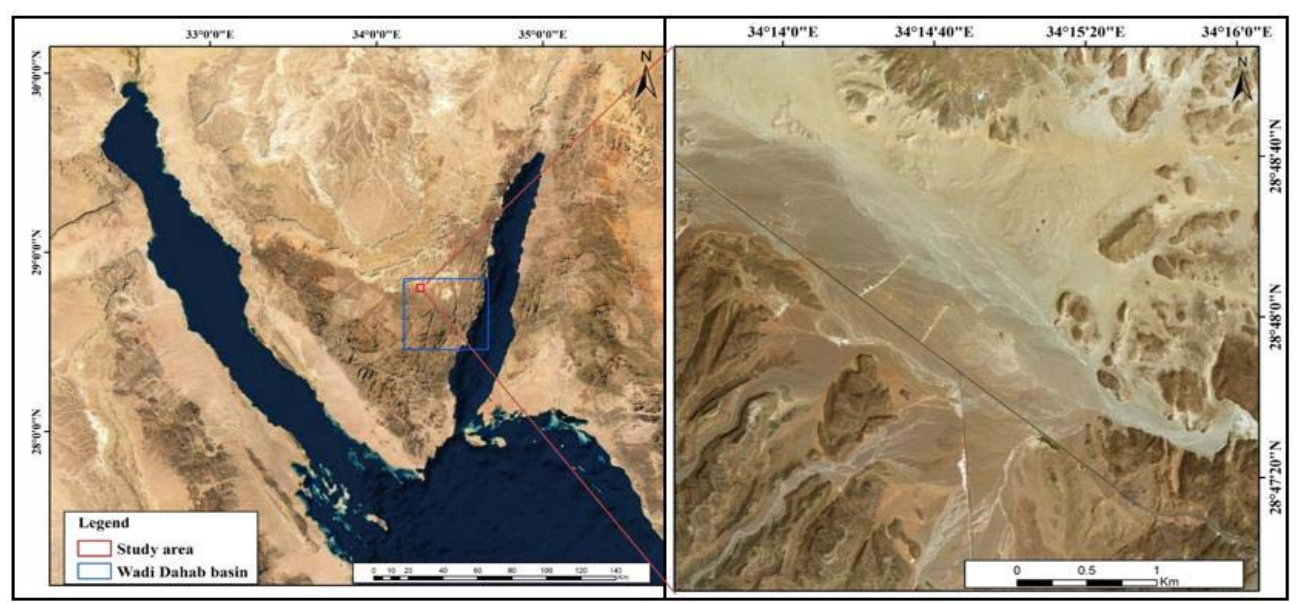

Figure 1: Google Earth Map Showing the Location of the Study Area.
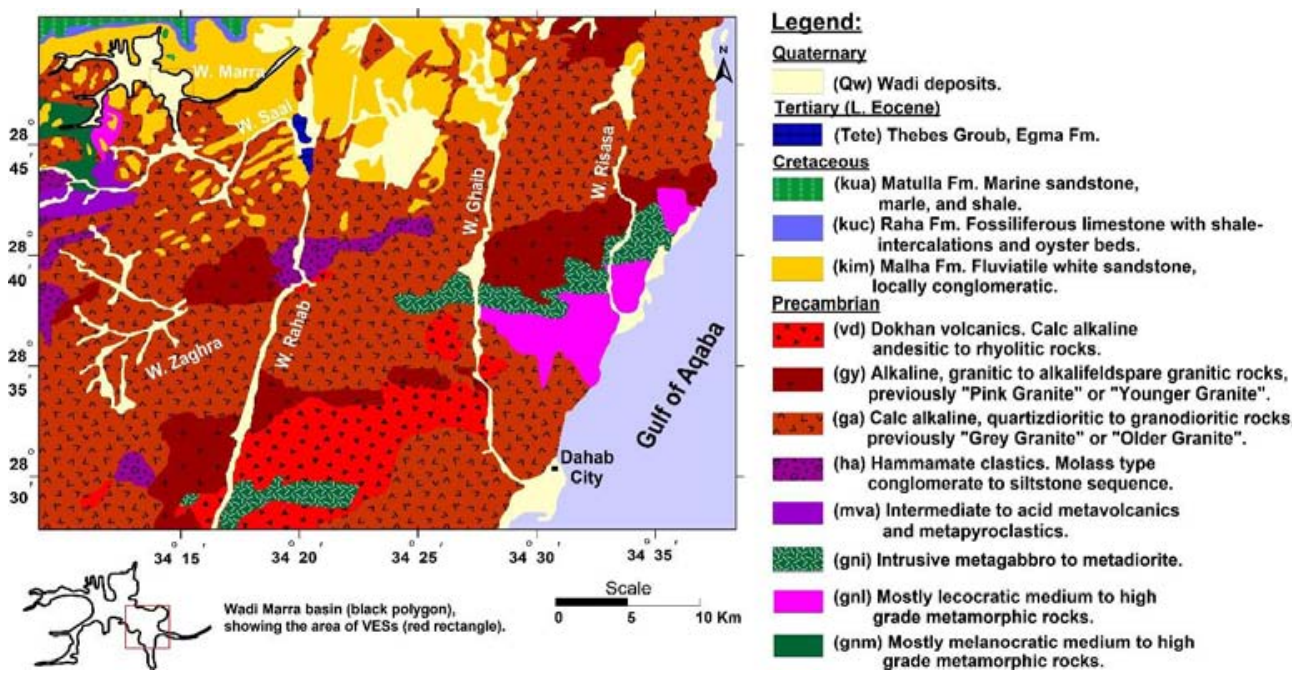

Figure 2: Geological Map of Dahab Basin Area, Including the Wadi Morra Basin (Klitzsch et al. 1987).

were constructed to illustrate the extension of the geoelectrical layers and the geometry of the aquifer (s) within the study area (Figure 6), which reflect both horizontal and vertical variations in lithology according to resistivity values. As a result of the quantitative interpretation of the VESs, five geoelectrical layers (A, B, C, D, and E) are detected and constructed in the geoelectric cross-sections. The ranges of resistivity and thickness of each geoelectric layer are listed in (Table 2), and the description of these geoelectrical layers from top to bottom is given as the following:

Geoelectrical Layer (A): This layer is consisting of a few thin layers, combined to represent the dry Quaternary Wadi deposits. It has a wide range of resistivity values, from 7 to $2962 \Omega$.m. The low resistivity corresponds to Quaternary alluvium that is consists of intruded clay with sand deposits, whereas the high resistivity value corresponds to boulders, gravel, sands, and sandstone. The thickness of this layer varies from $13 \mathrm{~m}$ at VES 7 to $28 \mathrm{~m}$ at VES 10.

Geoelectrical Layer (B): This layer has a small extension in the Wadi Morra area and was not observed at some VESs. It consists of

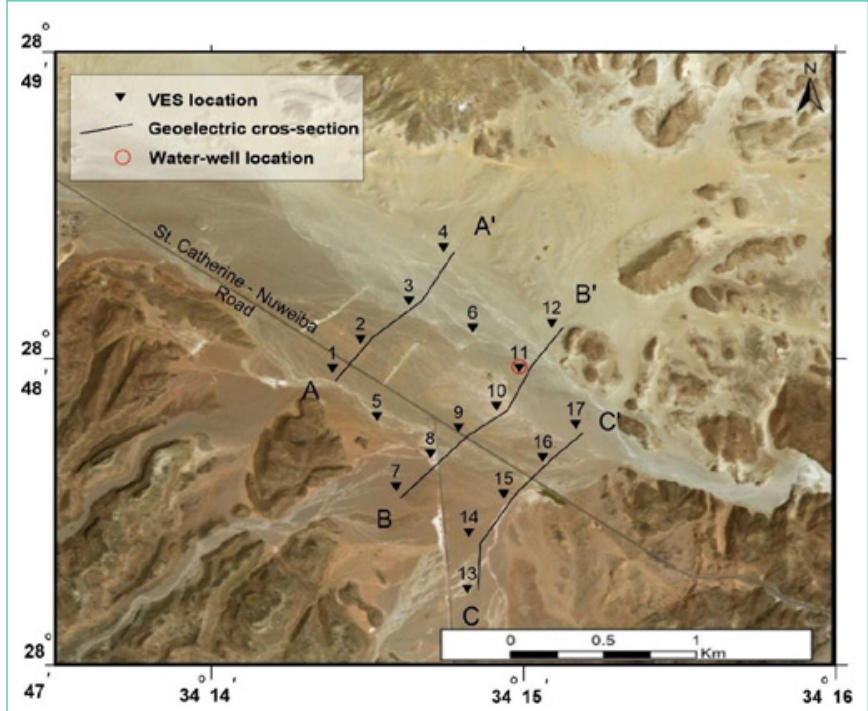

Figure 3: VES's and Cross-sections Distribution in the Study Area. 

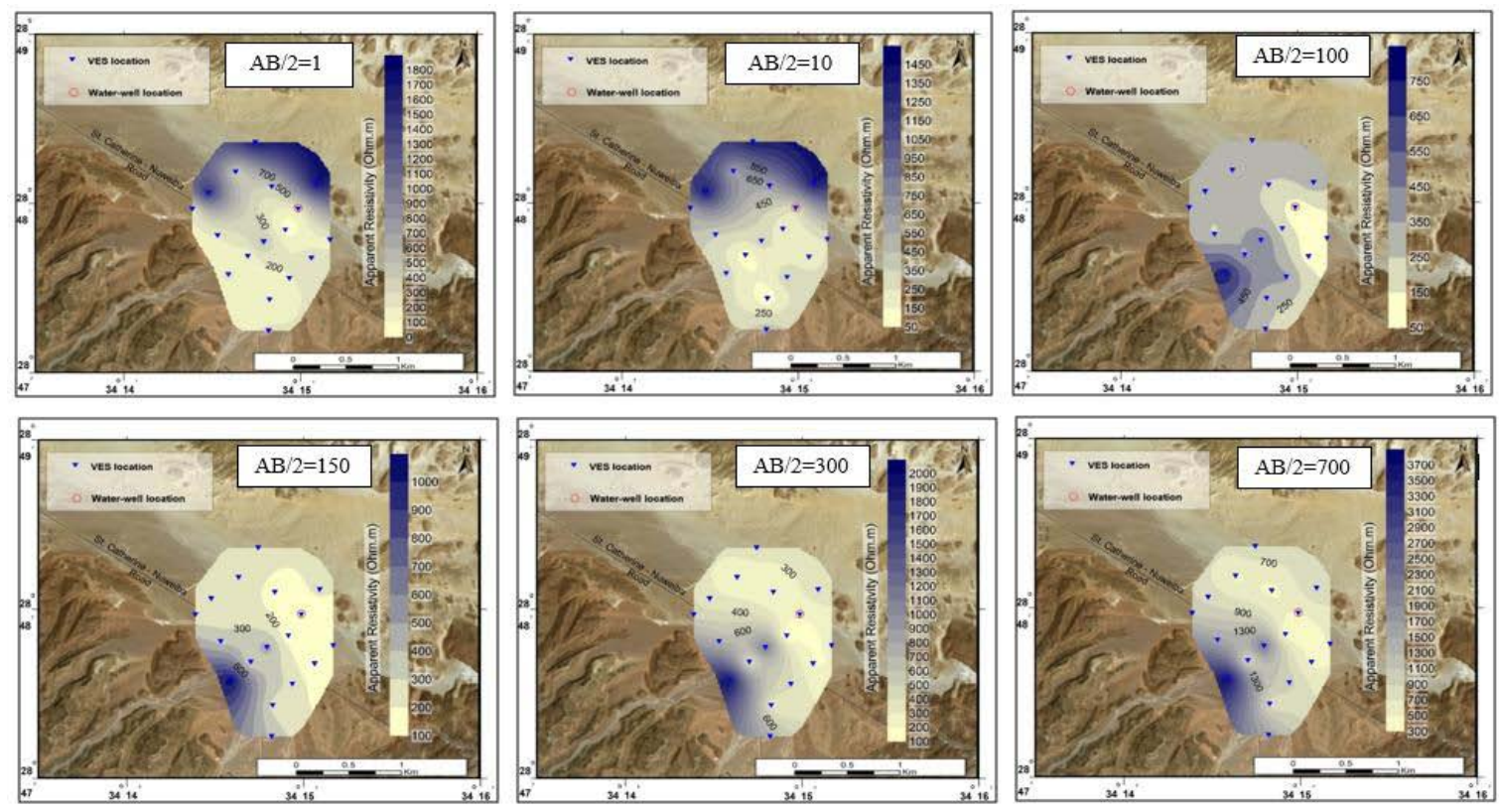

Figure 4: Iso-Apparent Resistivity Contour Maps.
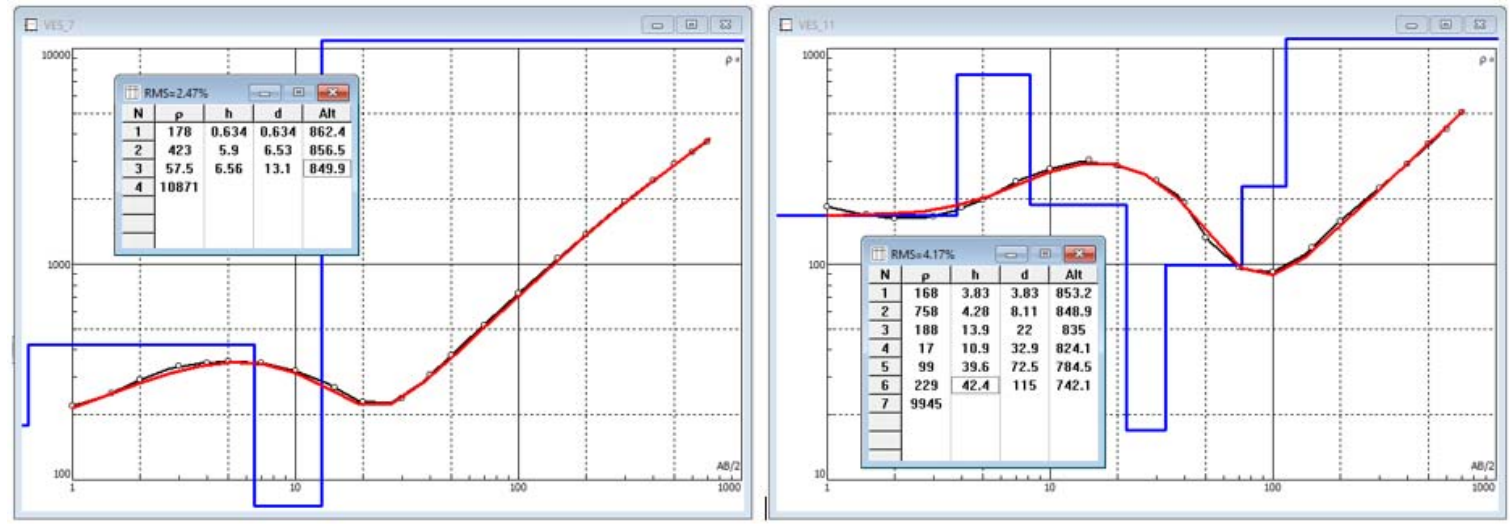

Figure 5: The Interpretation of VESs No. 7 and 11 by Using IPI2win Program.

silty and clayey sandstone with resistivity values ranging from 10 to $17 \Omega . \mathrm{m}$. The thickness of this layer ranging from 5 to $10 \mathrm{~m}$.

Geoelectrical Layer (C): This layer is observed underlays the layer (B) and represents the first aquifer in the study area (Nubian sandstone aquifer). It consists of water-bearing sandstone, which has resistivity values varying from 65 to $99 \Omega$.m. The thickness of this layer ranging from $30 \mathrm{~m}$ at VES 2 to $50 \mathrm{~m}$ at VES 10.

Geoelectrical Layer (D): This layer represents the second aquifer in the study area (Fractured water-bearing basement aquifer). It consists of fractured water-bearing basement, which has resistivity values varying from $175-229 \Omega$.m. The thickness of this layer ranging from $20 \mathrm{~m}$ at VES 2 to $46 \mathrm{~m}$ at VES 10 .

Geoelectrical Layer (E): This layer is represented by a massive basement. It has high resistivity values varying from 5423 to 29631 $\Omega . m$. The depths to the surface of the massive basement in the study area is ranging from $13 \mathrm{~m}$ at VES 7 to $133 \mathrm{~m}$ at VES 10 (Figure 7).

\section{Hydrogeologic setting}

The geoelectrical results referred to that there are two waterbearing geoelectrical layers ( $\mathrm{C}$ and $\mathrm{E}$ ) which represent two aquifers distributed in the study area are:

- $\quad$ Nubian sandstone aquifer (Layer C).

- $\quad$ Fractured basement aquifer (Layer D).

A description of each aquifer is given as the following:

Nubian sandstone aquifer (Layer C): This aquifer observed along the northern part of the Saint Catherine-Nuweiba road that dissects the Wadi Morra basin, while it is absent at the southern part of this road. It is due to the presence of a few faults F1, F2, and F4 (Figure 6), maybe these faults are connected to give only on fault along Saint Catherine-Nuweiba road. This aquifer consisting of water-bearing sandstone, which has resistivity values varying from 65 to $99 \Omega$.m (Figure $8 \mathrm{~A}$ ). The thickness of this layer ranging from $30 \mathrm{~m}$ at VES 2 to $50 \mathrm{~m}$ at VES 10 (Figure $8 \mathrm{~B}$ ), and it is completely absent 
Table 1: Resistivities, Thicknesses of each layer which deduced by the IPI2 win program.

\begin{tabular}{|c|c|c|c|c|c|c|c|c|c|}
\hline \multirow{2}{*}{ VES No. } & \multicolumn{2}{|c|}{ Layer 1} & \multicolumn{2}{|c|}{ Layer 2} & \multicolumn{2}{|c|}{ Layer 3} & \multicolumn{2}{|c|}{ Layer 4} & \multirow{2}{*}{$\begin{array}{c}\text { Layer } 5 \\
\rho 5\end{array}$} \\
\hline & م1 & h1 & $\rho 2$ & h2 & م3 & h3 & $\rho 4$ & h4 & \\
\hline 1 & $136,820,372,1131$ & $0.5,5,12,10$ & 10.3 & 6.2 & 29631 & & & & \\
\hline 2 & $3702,450,68,940$ & $0.4,0.7,6,3,19$ & 15 & 5 & 93 & 30 & 215 & 20 & 19422 \\
\hline 3 & $304,642,62,4410$ & $0.5,16,4.8,5$ & 13 & 9 & 77 & 37.8 & 175 & 25 & 9795 \\
\hline 4 & $4379,731,2217,99,1064$ & $0.3,1,5.3,17$ & 15 & 6 & 99 & 29 & 229 & 22 & 22692 \\
\hline 6 & $300,681,94,2440$ & $0.5,10,3,6$ & 12 & 9 & 70 & 38 & 209 & 40 & 6402 \\
\hline 7 & $178,423,57$ & $0.6,6,6.5$ & 10871 & & & & & & \\
\hline 8 & $61,930,17,12584,7,404$ & $0.3,0.2,1.8,2,6,15$ & 16011 & & & & & & \\
\hline 9 & $540,170,816,109$ & $0.8,0.5,2.5,23$ & 7251 & & & & & & \\
\hline 10 & $16.8,64,406,804$ & $0.16,1.7,11.5,15$ & 12 & 13 & 57 & 48 & 202 & 45 & 5423 \\
\hline 11 & $168,758,188$ & $3.8,4.3,14$ & 17 & 11 & 99 & 40 & 229 & 42 & 9945 \\
\hline 13 & $136,820,292,11,484$ & $0.5,3.4,3.4,3.9,16.3$ & 15140 & & & & & & \\
\hline 14 & $84,658,12,21123,11,359$ & $0.5,0.2,0.3,0.8,8,17$ & 23021 & & & & & & \\
\hline 15 & $218,70,11696,9,303$ & $0.7,1.7,2,5,21$ & 21010 & & & & & & \\
\hline 16 & $306,109,234$ & $1,1.7,25$ & 11 & 7 & 79 & 40 & 211 & 38 & 7510 \\
\hline 17 & $156,385,134$ & $2.5,11,10$ & 13 & 8 & 71 & 35 & 207 & 25 & 14200 \\
\hline
\end{tabular}

${ }^{*}(\rho)$ is a true resistivity $\&(h)$ is a thickness.

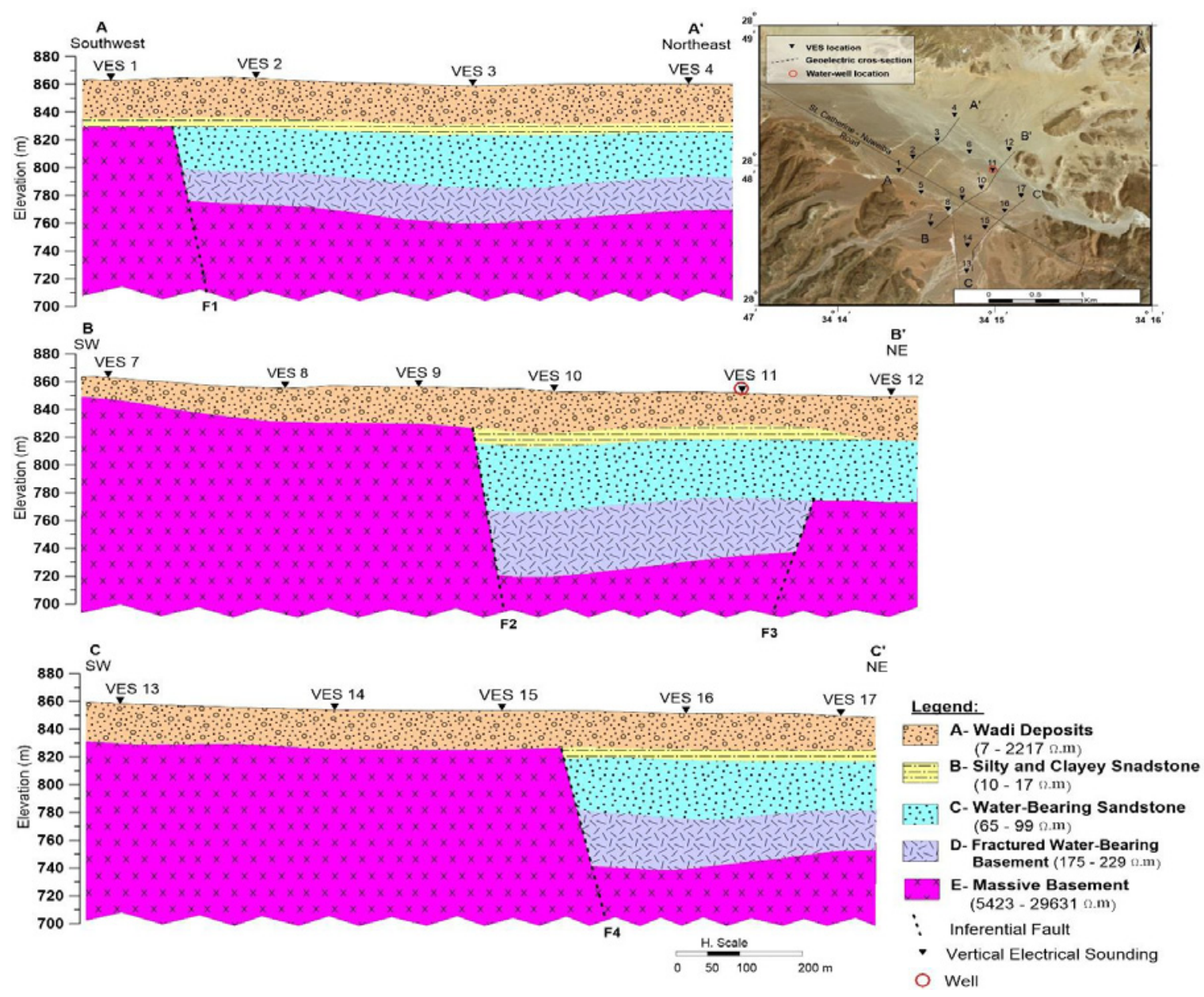

Figure 6: Geoelectric Resistivity Cross-sections 
Table 2: Resistivities, Thicknesses Ranges, and their Related Lithology.

\begin{tabular}{|c|c|c|c|}
\hline Layer & Resistivity Range $(\boldsymbol{\Omega} \mathbf{m})$ & Thickness $(\mathbf{m})$ & Lithology \\
\hline A & $7-2962$ & $13 \mathrm{~m}$ at VES $(7)-28 \mathrm{~m}$ at VES (10) & Wadi deposits \\
\hline B & $10-17$ & Thin layer ranges from 5 to $10 \mathrm{~m}$ & Water-bearing sandstone \\
\hline C & $65-99$ & $30 \mathrm{~m}$ at VES (2) $-50 \mathrm{~m}$ at VES (10) & Fractured water-bearing basement \\
\hline D & $175-229$ & $20 \mathrm{~m}$ at VES (2) $-46 \mathrm{~m}$ at VES (10) & Massive basement \\
\hline E & $5423-29631$ & & \\
\hline
\end{tabular}

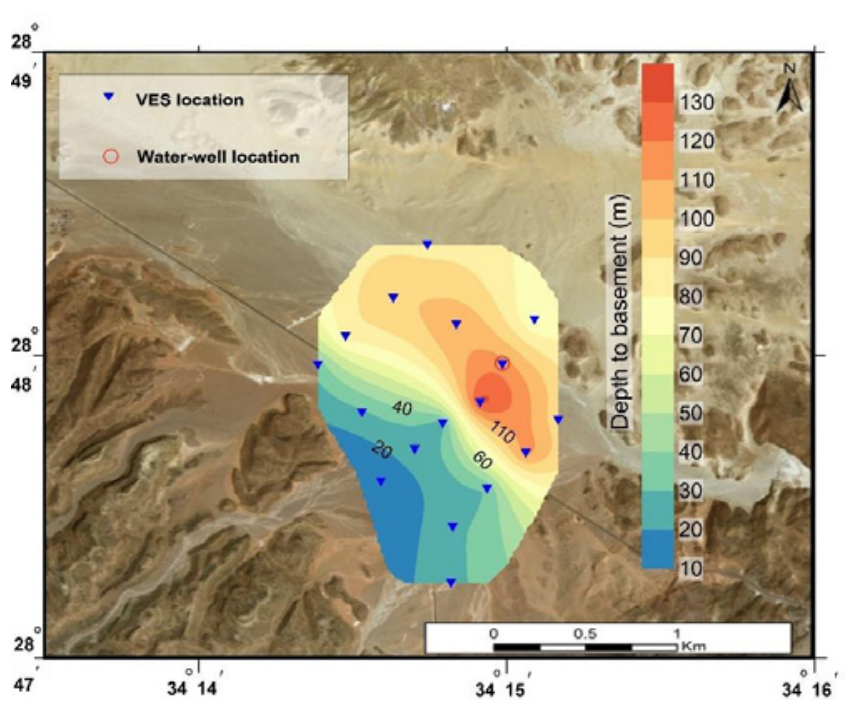

Figure 7: Depth to the Surface of Massive Basement (Layer E) Contour Map.

at the southern part, which affected by geoelectrical inferential faults $\mathrm{F} 1, \mathrm{~F} 2$, and F4.
Fractured basement aquifer (Layer D): The fractured waterbearing basement aquifer represents the second aquifer in the study area. It is observed underlays the Nubian sandstone aquifer at the northern part of the Saint Catherine-Nuweiba road. It has resistivity values varying from 175-229 $\Omega . m$ (Figure 8C). The thickness of this aquifer ranging from 20m at VES 2 to $46 \mathrm{~m}$ at VES 10 (Figure 8D).

Depth to nubian sandstone aquifer contour map and panel diagram: The depth of the water-bearing layer, which represents the Nubian sandstone aquifer, varies from 30 to $40 \mathrm{~m}$ from the ground surface (Figure $8 \mathrm{E}$ ). The minimum depth located at the central part of Wadi Morra (VESs 6 and 10) and increasing outsides with elevation increasing. Panel diagram has been created to show the Variation in the geoelectrical layer and the extension of the water-bearing Formations. Also, to show the structure affecting groundwater occurrences. The number of faults (Figure $8 \mathrm{~F}$ ) structurally controls the occurrence of groundwater in the study area. Saint Catherine Nuweiba road is approximately considered the boundary between the water-bearing layers and the basement (at the ground surface), the two aquifers are observed along the northern part of Saint Catherine - Nuweiba road, while it is absent at the southern part of this road.
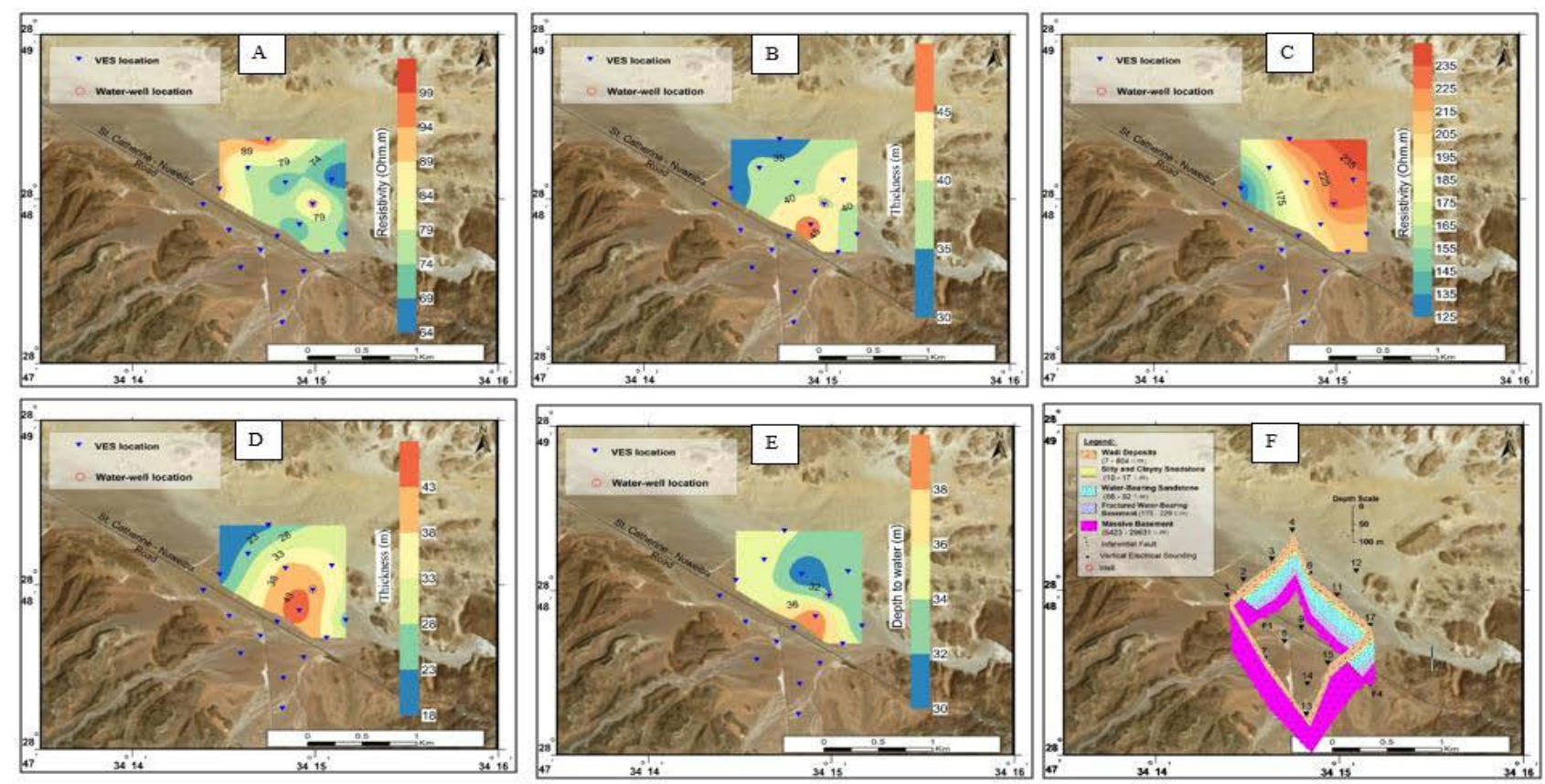

Figure 8: (A and B) True Resistivity and Thickness Contour Maps of Nubian Sandstone Aquifer Respectively, (C and D) True Resistivity and Thickness Contour Maps of Fractured Basement Aquifer Respectively, (E) Contour Map of Depth to Water-Bearing Layer, and (F) Panel Diagram Showing the Extension of Water Bearing Formations and Affecting Geoelectrical Faults. 


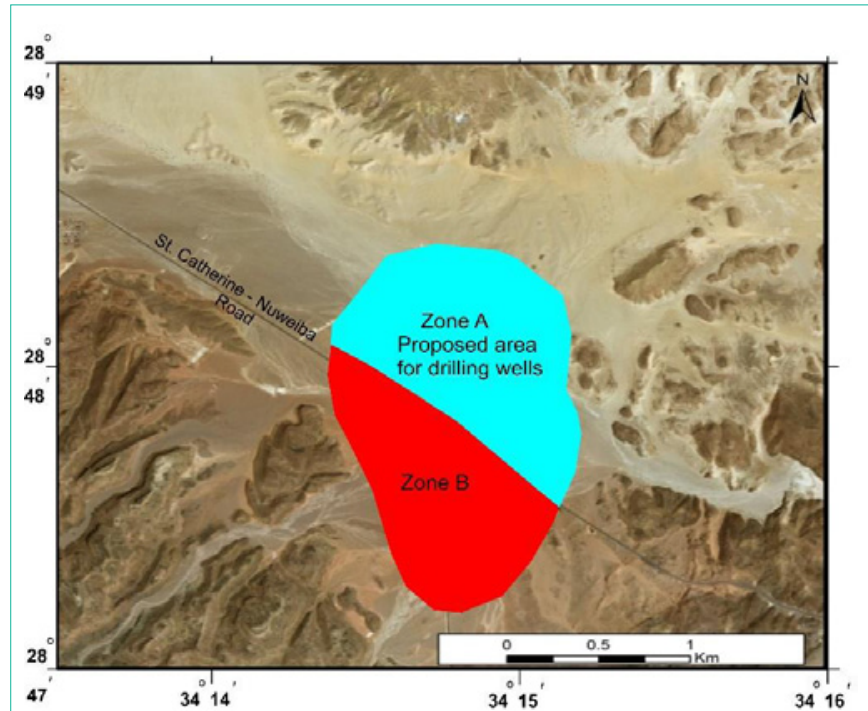

Figure 9: Recommendation map shows the proposed area for drilling groundwater wells.

\section{Conclusions and Recommendations}

There are two water-bearing geoelectrical layers according to the geoelectrical analysis; these layers represent two aquifers distributed in the study area. The first layer is layer $\mathrm{C}$ that represents the Nubian sandstone aquifer, and the second layer is layer $\mathrm{D}$ that represents the fractured basement aquifer. The Nubian sandstone aquifer is observed along the northern part of the Saint Catherine - Nuweiba road that dissects the Wadi Morra basin, while it is absent at the southern part of this road. It is due to the presence of a few faults. This aquifer consisting of water-bearing sandstone, which has resistivity values varying from 65 to $99 \Omega . \mathrm{m}$. The thickness of this layer ranging from 30 to $50 \mathrm{~m}$, and it is completely faded at the southern part, which affected by geoelectrical inferential faults F1, F2, and F4. The fractured water-bearing basement aquifer represents the second aquifer in the study area. It is observed underlays the Nubian sandstone aquifer at the northern part of the Saint Catherine - Nuweiba road. It has resistivity values varying from $175-229 \Omega . \mathrm{m}$. The thickness of this aquifer ranging from 20 to $46 \mathrm{~m}$. The study area can be divided into two zones according to groundwater occurrences (Figure 9), the first zone is the zone (A) where the groundwater is present, either in the Nubian sandstone aquifer or in the fractured basement aquifer and the second zone is the zone (B) where there is no groundwater at all due to the presence of basement rocks at a few depths. This research also recommends that the best places for drilling productive wells be at zone $\mathrm{A}$.

\section{References}

1. Hasanein AM. Comparative Study of the Effective Geomorphologic and Geologic Features on the Water Resources in Wadis Baba and Dahab, South Sinai, Egypt. Sed. of Egypt, Ain Shams Univ. 2007; 15: 35-52.

2. El-Arabi H Shendi, Mohamed H Geriesh, Mohamed M Mousa. Geophysical and hydrogeological studies on Wadi Saal Basin, Southern Sinai, Egypt. Egyptian Journal of Geology. 1997; 41: 871-908.

3. South Sinai. "Population Estimates by Governorate (Urban /Rural). 2018.

4. Shendi EH, Abouelmagd AA. New Approach for Ground Geophysics in the Development of Groundwater in the Basement Terrains (A Case Study from
South Sinai, Egypt). The $7^{\text {th }}$ Conf. Geology of Sinai for Development, Ismailia. 2004: 129-140.

5. Sultan M, Metwally S, Milewski A, Becker D, Ahmed M, Sauck W, et al. Modern Recharge to Fossil Aquifers: Geochemical, Geophysical, and Modeling Constraints. Journal of Hydrology. 2011; 403: 14-24.

6. Eissa MA. Application of Multi-Isotopes and Geochemical Modeling for Delineating Recharge and Salinization Sources in Dahab Basin Aquifers (South Sinai, Egypt). Hydrology. 2018; 5: 41.

7. Basheer AA, Alezabawy AK. Geophysical and Hydrogeochemica Investigations of Nubian Sandstone Aquifer, South East Sinai, Egypt: Evaluation of Groundwater Distribution and Quality in Arid Region. Journal of African Earth Sciences. 2020.

8. El Sabri MA. Sh. Evaluation of Water Resources and Its Impact on the Future Development in Wadi Dahab, Gulf of Aqaba, Sinai, Egypt. Egyptian Journal of Geology. 2016; 60: 1-16.

9. Sultan M, Arvidson RE, Duncan IJ, Stern RJ, El Kaliouby B. Extension of the Najd Shear System from Saudi Arabia to the Central Eastern Desert of Egypt Based on Integrated field and Landsat Observations. Tectonics. 1988; 7: 1291-1306.

10. Blasband B, White S, Brooijmans P, De Boorder H, Visser W. Late Proterozoic Extensional Collapse in the Arabian-Nubian Shield. Journal of the Geological Society of London. 2000; 157: 615-628.

11. Klitzsch E, List FK, Pohlmann G. Geological Map of Egypt, Conoco Coral and Egyptian General Petroleum Company, Cairo, Egypt, NH 36 SE South Sinai. Scale. 1987.

12. Abdallah AM, Adindani A, Fahmy N. Stratigraphy of Upper Paleozoic Rocks, Western Side of the Gulf of Suez, Egypt. Egyptian Geological Survey. 1963: $1-18$

13. Shata A. Hydrogeology of the Great Nubian Sandstone Basin, Egypt. Quarterly Journal of Engineering Geology. 1982; 15: 127-133.

14. El-Shazly EM, Abddel-Hady MA, El-Ghawaby MA, El-Kassas IA, EIShazly MM. Geology of Sinai Peninsula from ERTS-1 Satellite Images; Remote Sensing Research Project. Academy of Scientific Research and Technology, Cairo, Egypt. 1974: 20.

15. Omran A, Hahn M, Hochschild V, El-Rayes A, Geriesh M. Lithological Mapping of Dahab Basin, South Sinai, Egypt, Using ASTER Data; PFG Photogrammetrie, Fernerkundung, Geoinformation; Springer: Heidelberg, Germany. 2012: 711-726.

16. El-Kiki MF, Eweida EA, El Refeai AA. Hydrogeology of the Aqaba Rift Border Province. In Proceedings of the $3^{\text {rd }}$ Conference of the Geology and Sinai Development, Ismailia, Egypt. 1992: 91-100.

17. El Rayes A. Hydrogeological Studies of Saint Katherine Area, South Sinai, Egypt. Master's Thesis, Suez Canal University, Ismailia, Egypt. 1992: 95

18. Japan International Cooperation Agency JICA. Water Resources Research Institute (WRRI). South Sinai Groundwater Resources Study in the Arab The Republic of Egypt; Main Report; Pacific Consultants International: Tokyo, Japan. 1999.

19. Abouelmagd A, Sultan M, Sturchio NC, Soliman F, Rashed M, Ahmed M, et al. Paleoclimate record in the Nubian Sandstone Aquifer, Sinai Peninsula, Egypt. Quaternary Research. 2014; 81: 158-167.

20. Egyptian Meteorological Authority (EMA). Climatic Atlas of Egypt. Egyptian Meteorological Authority, Ministry of Transport and Communications, Cairo, Egypt. 1996.

21. Geb M. Factors Favoring Precipitation in North Africa: Seen from the Viewpoint of Present-Day Meteorology. Global and Planetary Change. 2000; 26: 85-96.

22. Mabrouk MA, Youssef AA, Diab MSh, Barseem MS. Geophysical Study on the Groundwater Occurrence in the Delta of Wadi Kid, Gulf of Aqaba, Sinai. The $7^{\text {th }}$ Conf. Geology of Sinai for Development, Ismailia. 2004: 279-288.

23. IPI2win program. Resistivity Sounding Interpretation Program, Moscow State University. Moscow, Russia. 2008. 